\section{Carter's energy problem}

As America freezes energy matters grow more important. Colin Norman reports from Washington on the continuing search for an energy policy

IT didn't take long for President Jimmy Carter to be brought face to face with the energy crisis. Within a week of taking office, he was forced to ask Congress for emergency powers to deal with a critical shortage of natural gas in parts of the eastern United Statesa shortage brought about by an extraordinarily cold winter and several years' lack of a coherent energy policy. Though at this stage Carter can do little more than spread the shortage around, urge people to be less profligate in their use of energy and pray for warmer weather, the new Administration is promising to set things right in the long term with a comprehensive energy policy, a strong conservation plan and an overhaul of the federal energy bureaucracy.

Clearly, energy matters are going to keep the Administration busy, but at least it will have no shortage of outside advice. In that regard, a mammoth study now being put together by the National Academy of Sciences is likely to prove particularly influential. Due to be completed by June 30 , the study is one of the most ambitious projects the Academy has yet undertaken. It involves some 250 people, sitting on a variety of panels and committees, who are now channelling their advice to a steering committee co-chaired by the ubiquitous Harvey Brooks, professor

\title{
Changing of the guard
}

- As the new Carter Administration settled into its first full week in office, selection of the second-level Presidential appointees began in earnest, but by the end of the week, none of the key science posts had been filled. The most important job, head of the Office of Science and Technology Policy (OSTP) and Science Adviser to the President, was still open following the departure of H. Guyford Stever on January 20. About the only sign of movement is that Carter has asked the Defense Secretary, Harold Brown, to draft a list of potential candidates for the OSTP post, a curious assignment since OSTP has little influence over defence matters, and most other Presidential appointments are being handled by a team in the White House.

As for the major science agencies, Donald Fredrickson, the popular director of the National Institutes of Health (NIH), had not heard by the end of last week whether he will be kept in his job. At a press conference, however, Joseph Califano, the new Secretary of Health Education and Welfare, promised to end the politicalisation of NIH, but he said he hadn't made up his mind about Fredrickson's future. Similarly, Robert Seamans Jr, has departed as head of the Energy Research and Development Administration, but no successor has been named. It is widely reported, however that Douglas Costle, a former staff member of the Congressional Budget Office has been chosen as head of the Environmental Protection Agency, to replace the alrcady-departed Russell Train.

About the only major scientific appointment so far is that of Patsy Mink, a former Congresswoman from Hawaii, to be Assistant Secretary of State in charge of science and technology affairs. The post was once held by Dixy Lee Ray, the former head of the Atomic Energy Commission who is now Governor of Washington State, but she quit with a blast at Henry Kissinger because of his indifference toward her office. The selection of Mink, a lawyer, for a post which many people consider should be held by a scientist, or at least by somebody well versed in scientific matters, will not do much to enhance the status of the office.

- Meanwhile, at the other end of Pennsylvania Avenue, Congress is finally getting itself in gear for the new session. The plan to reorganise the committees of the Senate, which was drafted last year by a special select committee, has now been picked over and amended by the Senate Rules Committee and it is expected to be debated by the full Senate this week. Although several more changes are anticipated, the chief committee alignments for science and technology affairs are likely to remain virtually as proposed by the select committee.

The Joint Committee on Atomic Energy, which has already been cut up by the House, will be completely done away with, and all jurisdiction for energy policy and energy research and development will be placed in an expanded Interior committee, under the chairmanship of Senator Henry Jackson. Responsibility for biomedical research will be consolidated in a new Committee on Human Resources, based on the old Labor and Public Welfare Committee, which means that Senator Edward Kennedy's subcommittee will retain its jurisdiction. The rest of the responsibility for science and technology, including overall science policy affairs, will be placed in an expanded Commerce Committee. Senator Adlai Stevenson, who chaired the select committee, is expected to end up with chairmanship of the key Commerce subcommittee dealing with science and technology.

The only major change from the select committee's proposals is that jurisdiction over the National Science Foundation (NSF) will go to the Human Resources Committee. On the face of it, a decision to put NSF affairs into a committee which deals with health and welfare rather than into the Commerce Committee, which deals with science, may seem a bit illogical. The reason is that Kennedy, whose NSF subcommittee now handles NSF matters, is a member of the Human Resources Committee but not of the Commerce Committee, and he wants to hang on to his NSF jurisdiction. That's the way Congress works.

On the House side, the Science and Technology Committee, which has picked up responsibility for nuclear research and development from the Joint Committee on Atomic Energy, has been reorganised. Chairmanship of the subcommittee on Science, Research and Development, which deals with NSF, has been assigned to Representative Ray Thornton, a Democrat for Arkansas. Energy matters will be handled by two sub-committees, one of which will deal with fossil energy and nuclear fission and fusion, while the other will deal with solar and geothermal energy, energy conservation and basic energy research. Rep. Walter Flowers, a longserving member from Alabama, claimed the chairmanship of the fossil and nuclear subcommittee, while Representative Mike McCormack, who was widely expected to get authority over nuclear matters, was left with the solar and geothermal subcommittee. Flowers' views on energy policy are little known, but his new post will give him plenty of visibility, a useful asset if, as expected, he decides to run for the Senate in 1978.

Colin Norman 